\title{
Niedawno odkryte piętnastowieczne freski w kościele parafialnym pod wezwaniem Bożego Ciała w Pręgowie k. Gdańska
}

Niecałe piętnaście kilometrów od Gdańska znajduje się niewielka, kaszubska miejscowość Pręgowo z malowniczym, czternastowiecznym kościołem parafialnym, wybudowanym $z$ kamienia polnego (ryc. 1). Do niedawna bardzo niewiele wiadomo było o jego średniowiecznym wystroju. Podjęte w latach 2008-2011 badania konserwatorskie przyczyniły się do odkrycia fresków ${ }^{1}$, stanowiących w okolicach Gdańska jedyny przykład niemal w całości zachowanego gotyckiego wystroju kościoła.

Niniejszy artykuł stanowi skrót mojej pracy magisterskiej, będącej pierwszym naukowym opracowaniem tych malowideł.

Za pierwszą osadę w Pręgowie uchodzi tzw. Popower Schlossberg - Góra Zamkowa - najprawdopodobniej jeden z pierwszych ośrodków chrześcijaństwa na Pomorzu Gdańskim ${ }^{2}$. W jej okolicach dokonano odkrycia skorup glinianych, datowanych na około $1200 \mathrm{r}$. - tego typu naczyniami posługiwały się rodziny słowiańskie ${ }^{3}$. W roku 1308 tereny te zostały podbite przez Zakon Krzyżacki, co wyznaczyło kres rządów lokalnych książąt ${ }^{4}$. Prawdopodobnie rozwój Pręgowa rozpoczął się w pierwszym okresie panowania Zakonu w Prusach ${ }^{5}$.

1 Fachowe badania konserwatorskie, współfinansowane przez Gminę Kolbudy, zostały przeprowadzone w latach 2008-2011 pod kierunkiem artysty-plastyka i konserwatora mgr Jolanty Pabiś-Gagis oraz konserwatora mgr Beaty Sobieszek-Nieścior. Inspektorami nadzoru prac konserwatorskich były: mgr Dorota Szmyt i Agnieszka Herzog-Fiebig z Wojewódzkiego Urzędu Ochrony Zabytków w Gdańsku (Dział Zabytków Ruchomych). Sprawy techniczne powierzono Grzegorzowi Sobczykowi oraz Markowi Jakubowskiemu. Autorem badań specjalistycznych jest mgr Maria Rogoż (Laboratorium Chemii Konserwatorskiej).

2 B. Lemke, Chronik von Prangenau im Radauental - ein Heimatbuch geschrieben zur Feier der 600 jaehrigen Bestehens des Dorfes und Der Kirche, Danzig 1923, s. 6.

Ibidem.

4 G. Labuda, Kaszubi i ich dzieje, Gdańsk 1996, s. 110.

5 B. Lemke, Chronik von Prangenau im Radauental..., s. 6. 
Istnieją przypuszczenia, że w $1396 \mathrm{r}$. Konrad von Jungingen podarował wieś z kościołem klasztorowi sióstr brygidek z Gdańska. Domniemana darowizna nie jest jednak potwierdzona bezpośrednimi dowodami ${ }^{6}$. Nie zachowały się też żadne dane dotyczące stosunków własnościowych tamtejszych terenów w XIII i XIV stuleciu?. Zakonowi podlegało wówczas wiele innych posiadłości w pobliżu Pręgowa, m.in. Bielkowo i Kolbudy z Młynem. W 1396 r. Konrad von Jungingen przekazał obydwie miejscowości klasztorowi kartuskiemu. „Można stąd przypuszczać - pisze Stefania Kamińska iż do Zakonu należało także Pręgowo, gdzie prawdopodobnie, wybudował on kościół"'. Położony na wzniesieniu kościół jest świątynią orientowaną, zbudowaną na planie prostokąta i reprezentuje typ świątyni salowej z niewydzielonym prezbiterium. Na zewnątrz, w bryle świątyni w Pręgowie, pojawia się kilka motywów bardzo charakterystycznych dla architektury krzyżackiej (profilowana cegła, blendy arkadowe) (rys. 2). Podobne rozwiązania dekoracyjno-architektoniczne zastosowano w dominikańskim kościele św. Piotra i Pawła w Chełmnie, wzniesionym w trzeciej ćwierci XIV stulecia9. Niewykluczone, że Zakon Krzyżacki wzniósł nowy kościół na miejscu pierwotnej świątyni, a do jego budowy zatrudnił rzemieślników przybyłych z terytoriów niemieckich.

Malowidła rozmieszczone są na wschodniej, południowej i północnej ścianie świątyni. Na ścianie wschodniej, naprzeciw wejścia do kościoła, widnieją trzy przedstawienia: Chrystus w otoczeniu narzędzi męki Pańskiej (określanych w literaturze jako Arma Christi bądź Arma Passionis), postać św. Jakuba Młodszego oraz wyobrażenie Veraikonu. Ostatnie malowidło umieszczone jest powyżej linii obecnego, wtórnego stropu, na wschodniej ścianie tarczowej, będącej pozostałością po oryginalnym sklepieniu kolebkowym. Na ścianie południowej zachowały się cztery wyobrażenia apostołów. W obrębie ściany północnej ukazane są kolejno od strony wschodniej: scena Sądu Ostatecznego, przedstawienie Matki Boskiej Apokaliptycznej (pole ściany tarczowej nad wejściem do zakrystii) oraz umieszczone powyżej Ukrzyżowanie, a także przedstawienie świętego Jakuba Starszego.

Przedstawienie Chrystusa w otoczeniu Arma Passionis (ryc. 3.) jest jedną $\mathrm{z}$ trzech głównych, wielkoformatowych kompozycji i znajduje się w lewym

6 S. Kamińska, Klasztory brygidek w Gdańsku, Elblagu i Lublinie. Założenie i uposażenie, Gdańsk 1970, s. 97.

7 Ibidem.

8 Ibidem, s. 98.

9 Gotik im Ordensland-Architektur, Skulptur und Malerei, red. J. Raczkowski, Thorn 2002, s. 43. 
rogu prezbiterium. W centralnej partii czerwono malowanej kwatery widnieje postać Chrystusa. Zbawiciel ukazany jest frontalnie, w półpostaci, z lekko zgiętymi w łokciach, opuszczonymi ramionami. Flankujące go dwie postacie aniołów trzymają $\mathrm{w}$ dłoniach, odpowiednio, liść palmowy oraz sztylet. Pole kwatery wypełnione jest wyobrażeniami pozostałych przedmiotów narzędzi męki Pańskiej.

W górnej strefie kompozycji (poza obrębem czerwonej kwatery) ukazane są dwie sceny: Chrystus przed Poncjuszem Piłatem oraz Chrystus przed Kajfaszem. Obu scenom towarzyszą dodatkowo dwie niezidentyfikowane postaci. Znajdująca się w obrębie pierwszej sceny ma na sobie błękitne szaty. Widniejące nad jej głową kontury nimbu pozwalają domniemywać, że chodzi tu o przedstawienie świętego. Towarzysząca drugiej scenie postać odziana jest w ciemne szaty. Partie przedstawiające twarze obydwu osób nie zachowały się do naszych czasów. Nad ich głowami widnieją delikatnie zaznaczone sekwencje falistych linii. Lewy bok kompozycji zamyka postać brodatego mężczyzny z włócznią, zwróconego twarzą ku ołtarzowi. Trzymana w prawicy otwarta księga zwrócona jest stronicami do widza. Niewykluczone, że jest to przedstawienie św. Longinusa, rzymskiego żołnierza, który miał przebić włócznią bok Chrystusa.

Po drugiej stronie ołtarza (w partii pierwotnego sklepienia), znajduje się przedstawienie chusty św. Weroniki (Veraikon) (ryc. 4). W centralnym polu widnieje twarz Chrystusa, zbliżona kształtem do owalu. Wzrok Zbawiciela skierowany jest ku dołowi - jego głowę (podobnie jak w pozostałych przedstawieniach) otacza stylizowany nimb krzyżowy. Boczne krawędzie chusty pokrywa bogata dekoracja florystyczna.

W dolnej partii ściany wschodniej znajduje się wyobrażenie św. Jakuba Młodszego (ryc. 5). Święty przedstawiony został tutaj jako brodaty mężczyzna, odziany w długą, biało-czerwoną szatę. W prawej dłoni trzyma zakrzywioną, pielgrzymią laskę, w lewej - zamkniętą księgę.

Ściana południowa pozbawiona jest rozbudowanych scen figuralnych. Znajdują się na niej wyłącznie przedstawienia czterech apostołów. W partii ściany międzyokiennej widnieje postać św. Filipa Apostoła (ryc. 6). Święty odziany jest w błękitno-czerwoną szatę. W prawej dłoni trzyma swój atrybut - równoramienny krzyż, w lewej - księgę. Przedstawienie kolejnego apostoła znajduje się za ołtarzem bocznym ściany południowej. Zły stan zachowania oraz brak atrybutów uniemożliwiają jego dokładną identyfikację. Został tu przedstawiony jako brodaty mężczyzna, odziany w błękitno-czerwoną szatę.

Następne dwa przedstawienia apostołów (św. Bartłomiej i św. Tomasz) znajdują się po drugiej stronie bocznych drzwi kościoła. Postać 
św. Bartłomieja (ryc. 7) trzyma w prawicy przedmiot zbliżony kształtem do noża. Św. Tomasz wyposażony jest $\mathrm{w}$ atrybut przypominający kształtem węgielnicę (ryc. 8). Przedstawieniom św. Tomasza oraz św. Bartłomieja towarzyszą zachowane fragmenty malowanych konsolek.

Największą i zarazem najbardziej reprezentacyjną sceną jest przedstawienie Sądu Ostatecznego na ścianie północnej (ryc. 9). Scena ta stanowi swoisty punkt kulminacyjny całego programu malowideł. Zasiadający na podwójnej tęczy Chrystus-Sędzia odziany jest w długi, czerwono-malachitowy płaszcz. Chrystus prezentuje swoje rany: prawą dłonią dotyka zakrwawionego boku, na lewej, lekko uniesionej dłoni demonstruje ślad po gwoździu. Rany widnieją również na stopach Zbawiciela, spoczywających na wewnętrznej sferze tęczy. Z kącików ust Chrystusa wyłaniają się stylizowane liście lilii oraz miecz. Wnętrze tęczy Chrystusowej wypełnione jest formami przypominającymi zachodzące na siebie łuski.

Widniejące po prawicy Chrystusa postacie to najprawdopodobniej święci: Paweł i Jan Chrzciciel (odziany w błękitny płaszcz oraz żółtą tunikę, przywodzącą na myśl futro z wielbłądziego włosienia). Tuż poniżej znajduje się przedstawienie św. Pawła z księgą. Poniżej tęczy, na której siedzi Chrystus, znajdują się wyobrażenia Słońca i Księżyca. Ciała niebieskie ukazane są w postaci groteskowych, owalnych masek o zdeformowanych rysach twarzy (głębokie oczodoły, rozczłonkowane partie nosa, pomarszczone, wykrzywione $\mathrm{w}$ demonicznym grymasie wargi). $\mathrm{Z}$ błękitno-czerwonych obwódek masek wyrastają pojedyncze, nieregularne wypustki, przywodzące na myśl promienie.

U samego dołu przedstawienia rozciąga się scena pochodu piekielnego. Osiem niewiast, odzianych w czerwone, brązowe i zielone szaty podąża w stronę paszczy Lewiatana. Procesji potępieńców towarzyszą groteskowe postacie demonów - owłosionych, rogatych stworzeń, wyposażonych w trójzębne widły. Z jego szeroko rozwartej paszczy bucha piekielny ogień w postaci wąskich, falistych, poziomo biegnących płomieni. U dołu kompozycji widnieją także nieregularnie rozmieszczone, skąpane w ogniu kotły z duszami potępionych oraz ptasia postać, z której pozostały jedynie kontury. Scena Sądu Ostatecznego nie zachowała się w pełni. Ponad Chrystusem-Sędzią zapewne rozciągało się niebo - ta partia została zniszczona na skutek wykucia okna w XVIII w.

U wejścia do zakrystii znajduje się szczątkowo zachowane malowidło ukazujące Matkę Boską Apokaliptyczną z Dzieciątkiem (ryc. 10). Pozostały po nim kontury, fragmenty korony i płaszcza oraz promienista gloria w kolorystyce ugru, czerni i czerwieni. $\mathrm{Z}$ wazonu umieszczonego w prawym, 
dolnym rogu wyobrażenia wyłania się dekoracyjna wić roślinna oraz kwiaty lilii. Tuż nad wejściem do zakrystii znajdowało się wyobrażenie Ukrzyżowania (ryc. 11), z którego zachowała się jedynie pionowa, czerwona belka krzyża z białą plamą u dołu - być może pozostałością po nogach Chrystusa - oraz pojedyncze fragmenty wici roślinnej z motywami kwiatów.

$\mathrm{Na}$ ścianie północnej, po prawej stronie od drzwi do zakrystii znajduje się przedstawienie św. Jakuba Starszego z przewieszoną przez ramię torbą. $\mathrm{Na}$ okalanej nimbem głowie widnieje brązowy kapelusz z rondem. Święty trzyma w prawej ręce laskę wędrowca oraz różaniec. Kapelusz oraz pierś ozdobione są motywem muszli (ryc. 12). Glify okien ściany północnej (drugie od prawej) oplata bogaty ornament w postaci dwubarwnej wici roślinnej z pojedynczymi motywami łodyg i kwiatów (ryc. 13.). Jest to jedyny zachowany do naszych czasów przykład gotyckiej dekoracji okiennej z tego kościoła.

Pierwszym malowidłem odkrytym przez zespół konserwatorów było umieszczone w części strychowej przedstawienie Veraikon ${ }^{10}$. W trakcie oczyszczania powierzchni ścian dokonano odkrycia następnych partii polichromii gotyckich (zacheuszki, malowidło Chrystusa w otoczeniu Arma Passionis, Sąd Ostateczny, wyobrażenie Matki Boskiej, Scena Ukrzyżowania, postacie apostołów oraz dekoracyjną wić roślinną, oplatającą ościeża okna gotyckiego). Prace konserwatorskie zostały definitywnie zakończone w listopadzie 2011 r. Wówczas dokonano na ścianie południowej dwóch nowych, ostatnich już odkryć malarskich - pary apostołów, stojących na malowanych konsolkach.

Ze względu na odmienną technikę i czas powstania fresków, konserwatorzy dokonali podziału malowideł na dwa zespoły: zacheuszki oraz przedstawienia figuralne ${ }^{11}$. Te pierwsze powstały wcześniej i wykonane zostały techniką fresku mokrego z wyciśniętym rysunkiem w mokrej zaprawie ${ }^{12}$. Drugą grupę malowideł stanowią partie figuralne i ornamentalne. Ich kolorystyka biel, ugier, czerwień żelazowa, minia, czerń i zieleń malachitowa - jest bardzo charakterystyczna dla tamtego okresu ${ }^{13} \mathrm{i}$ występuje we wszystkich partiach.

Nie wiadomo, kto był twórcą pręgowskich fresków. Wśród zachowanych malowideł ściennych na terenie Prus brakuje dla nich analogii

10 J. Pabiś-Gagis, Wstępny opis inwentaryzacyjny, stan zachowania, założenia i program, oraz wycena prac konserwatorskich dla gotyckiej wprawy zabytkowej, pobiat i fragmentów polichromii ściennych $z$ kościoła $w$ Pręgowie (w pracy brakuje numeracji stron, stosuję więc numerację własną - G.Z.-K.).

11 Ibidem, s. 3.

12 Ibidem, s. 1.

13 Ibidem, s. 3. 
warsztatowych. Zapleczem warsztatów artystycznych były miasta i sieci klasztorne - w niektórych przypadkach klasztory korzystały również z usług świeckich artystów działających w miastach. Wystrój artystyczny miejskich kościołów i katedr bardzo często operował rozbudowanymi, skomplikowanymi programami ikonograficznymi, w przeciwieństwie do lapidarnych, niekiedy celowo uproszczonych środków artystycznych, właściwych sztuce prowincjonalnej. Fundatorem malowideł był najprawdopodobniej zakon sióstr brygidek z Gdańska - jako zamożne zgromadzenie z pewnością dysponowały środkami finansowymi, pozwalającymi wzbogacić wnętrze świątyni odpowiednim wystrojem malarskim. Freski te powstały w konkretnym celu - ukazywały w formie wizualnej podstawowe dogmaty wiary.

Analizowane przeze mnie malowidła wykazują wyraźne powinowactwa ze stylem około roku 1400. Cechy owego stylu zauważyć można w sposobie udrapowania szat. Jest to szczególnie widoczne w partiach draperii św. Bartłomieja, św. Filipa, św. Jakuba Młodszego oraz św. Pawła - z podtrzymujących atrybuty ramion apostołów spływają miękkie, kaskadowe fałdy szat, układające się w charakterystyczny kształt. W partiach szat św. Bartłomieja zachowały się śladowe fragmenty ciemno-błękitnego modelunku, świadczące o dążeniu do nadania formom przestrzenności.

Najbliższe im w Prusach realizacje można znaleźć m.in. na zamku w Malborku, w sypialni wielkich mistrzów (postacie św. Doroty i św. Katarzyny z 1404 r. autorstwa malarza Piotra). Święci trzymają w dłoniach atrybuty poprzez szaty - ich charakterystyczna, miękko ukształtowana forma jest bardzo zbliżona do przedstawień szat Apostołów z Pręgowa. Podobne formy pojawiają się również w malarstwie ściennym kościoła parafialnego w Zieleniu (ok. 1420 r.) - postacie są smukłe, fałdy ich szat cechuje miękki układ, barwy odznaczają się delikatnym modelunkiem.

Kolejnym przykładem malarstwa ściennego zbliżonego do stylistyki malowideł z Pręgowa są datowane na drugą ćwierć XV w. freski z kościoła w Mariance. Ukazane na neutralnym, zdobionym wicią roślinną tle sylwetki apostołów odznaczają się masywnymi proporcjami. Zarówno motyw dwubarwnej wici roślinnej, jak i proporcje postaci świętych oraz obfite kaskady fałd budzą pewne skojarzenia ze stylistyką pręgowskiego malarstwa. Wskazane analogie pozwalają ogólnie datować malowidła w kościele w Pręgowie na pierwszą połowę XV w.

Freski z Pręgowa koncentrują się wokół kwestii Eucharystii (Vir Dolorum, Arma Passionis, Chrystus pokazujący rany w Sądzie Ostatecznym), ofiary (Veraikon, Ukrzyżowanie), odkupienia (Sąd Ostateczny), a także eklezjologii (Maria Apokaliptyczna, apostołowie). Silne wyeksponowanie wątków 
eucharystycznych może być wskazówką co do celu i okoliczności powstania omawianych malowideł.

W tym kontekście należałoby wspomnieć o husytyzmie, który z Czech trafił na tereny Śląska, Rzeczypospolitej oraz Prus w I połowie XV stulecia. Husytyzm zajmował określone stanowisko wobec sztuki w kościele. Według Husa, dotychczasowa sztuka nierzadko przedkładała wartości artystyczne ponad religijne, odciągając tym samym uwagę wiernych od treści duchowych ${ }^{14}$. Husyci wkroczyli na tereny pruskie po roku $1430^{15}$. W sierpniu 1433 r. oddziały wojsk husyckich pod dowództwem czeskiego hetmana Jana Czapka napadły na Pelplin, spaliły tamtejszy kościół i klasztor, a w niecały miesiąc później wtargnęly na tereny Nowej Marchii - wkrótce potem opanowały miasto Gdańsk i jego okolice ${ }^{16}$. Biorąc pod uwagę eucharystyczną i eklezjologiczną wymowę ideową malowideł ściennych w Pręgowie, nie należy wykluczać prawdopodobieństwa, że powstały one jako forma reakcji na poglądy głoszone przez husytów.

Obok standardowego, powszechnego repertuaru motywów ikonograficznych pojawiają się unikatowe, dla których nie udało się, jak do tej pory, znaleźć analogii. Należą do nich motywy łusek, wypełniających pole pod tęczą, nietypowa konwencja ukazania Słońca i Księżyca, a także sylwetka ptaka, widniejąca w dolnej części sceny Sądu Ostatecznego. Owe rzadkie motywy ikonograficzne nie mają odpowiedników w gotyckiej sztuce Pomorza Wschodniego - ze względu na brak jakichkolwiek analogii ich geneza wciąż pozostaje nieodgadniona. Żywiący się trupami grzeszników ptak pojawia się w ustępach z Apokalipsy św. Jana ${ }^{17}$ - nigdy jednak nie był uwzględniany przez artystów jako samodzielny motyw ikonograficzny. Czy fakt umiejscowienia ptasiej postaci w scenie Sądu Ostatecznego w Pręgowie można uznać za zjawisko indywidualnej interpretacji treści Pisma Świętego? To pytanie pozostaje otwarte.

Pomimo licznych ubytków, malarstwo pręgowskie stanowi jedyny przykład niemalże w całości zachowanego programu ikonograficznego na tych terenach. Analogie są stosunkowo nieliczne i nie odnoszą się do całości, lecz do

14 T. Mroczko, Idee protoreformacji a malarstwo $w$ Polsce, [w:] Studia renesansowe, t. 4, red. M. Walicki, Wrocław 1964, s. 471.

15 J. Macek, Husyci na Pomorzu i w Wielkopolsce, Warszawa 1955, s. 61.

16 Ibidem, s. 74.

17 Cf. Apokalipsa św. Jana, Zagłada Wrogich Narodów (pierwsza walka Zwycięskiego Słowa, 9, 17-18). 
pojedynczych elementów składających się na repertuar fresków w Pręgowie. Trudno zatem o wskazanie jakiegokolwiek konkretnego odpowiednika, zarówno na terenie Pomorza, jak i Europy.

W kontekście rozważań nad osobliwym charakterem gotyckich fresków z Pręgowa należy wziąć pod uwagę fakt, że obraz malarstwa ściennego na terenach Pomorza Wschodniego wykazywał swoistą „odrębność i niezależność artystyczną" względem innych okolic. Na niejednolite oblicze sztuki pomorskich terenów składa się niewątpliwie jej kosmopolityczny syntetyzm, będący wynikiem wzmożonych kontaktów $\mathrm{z}$ miastami handlowymi ${ }^{18}-$ sprzyjały one szybkiemu rozprzestrzenianiu się „nowych trendów i tendencji”" ${ }^{19}$.

Naśladownictwo architektury w malarstwie ściennym jest jednym z częściej występujących zjawisk w sztuce Pomorza Wschodniego. Freski w Pręgowie nie stanowią pod tym względem żadnego odstępstwa - świadectwem tego są zachowane kontury malowanych konsolek umieszczonych pod postaciami apostołów na ścianie południowej. Również ich program ideowy oraz sposoby rozplanowania poszczególnych motywów i przedstawień we wnętrzu kościoła (umieszczanie malowideł na ścianach tarczowych, artykułowanie ścian postaciami świętych) nie odbiegają od cech właściwych dekoracjom malarstwa ściennego na Pomorzu.

Zespół malowideł ściennych z Pręgowa wpisuje się w ogólnie przyjęty kanon ikonograficzny. Jednocześnie jest on przykładem rzadkich redakcji niektórych tematów.

\section{Bibliografia}

Apokalipsa św. Jana, Zagłada Wrogich Narodów (Pierwsza walka Zwycięskiego Słowa, 9, 17-18).

DOMASŁOWSKI J., Malarstwo ścienne, [w:] J. Domasłowski, A. S. Labuda, A. Karłowska-Kamzowa, Malarstwo gotyckie na Pomorzu Wschodnim, Warszawa-Poznań 1971.

Gotik im Ordensland - Architektur, Skulptur und Malerei, red. J. Raczkowski, Thorn 2002.

KAMIŃSKA S., Klasztory brygidek w Gdańsku, Elblagu i Lublinie. Założenie i uposażenie, Gdańsk 1970.

18 J. Domasłowski, Malarstwo ścienne, [w:] J. Domasłowski, A. S. Labuda, A. Karłowska-Kamzowa, Malarstwo gotyckie na Pomorzu Wschodnim, Warszawa-Poznań 1971, s. 221.

19 Ibidem, s. 223. 
Niedawno odkryte piętnastowieczne freski w kościele parafialnym...

LEMKE B., Chronik von Prangenau im Radauental - ein Heimatbuch geschrieben zur Feier der 600 jaehrigen Bestehens des Dorfes und Der Kirche, Danzig 1923. LABUDA G., Kaszubi i ich dzieje, Gdańsk 1996.

MROCZKO T., Idee protoreformacji a malarstwo $w$ Polsce, [w:] Studia renesansowe, t. 4, red. M. Walicki, Wrocław 1964.

MACEK J., Husyci na Pomorzu i Wielkopolsce, Warszawa 1955.

PABIŚ-GAGIS J., Wstępny opis inwentaryzacyjny, stan zachowania, założenia i program, oraz wycena prac konserwatorskich dla gotyckiej wprawy zabytkowej, pobiał i fragmentów polichromii ściennych $z$ kościoła w Pręgowie. 


\section{Aneks}

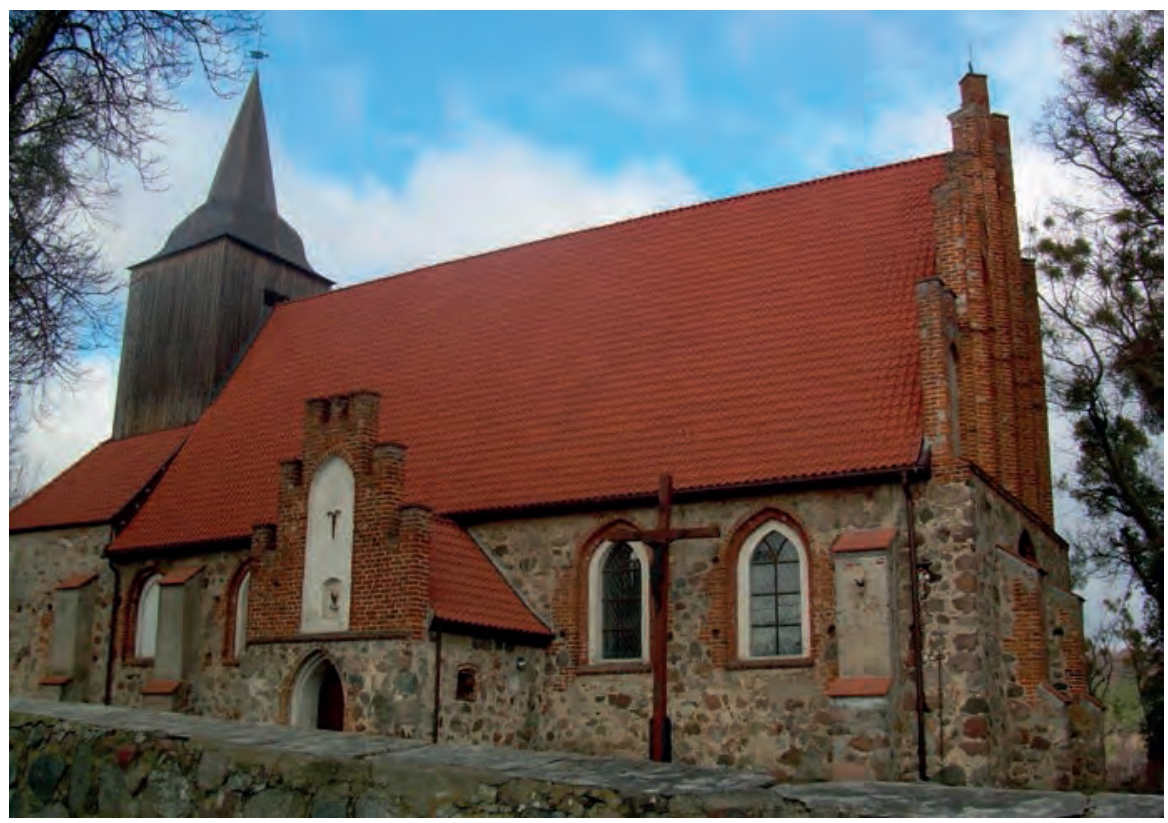

Ryc. 1. Kościół parafialny p.w. Bożego Ciała w Pręgowie, I poł. XIV w., widok z zewnątrz.

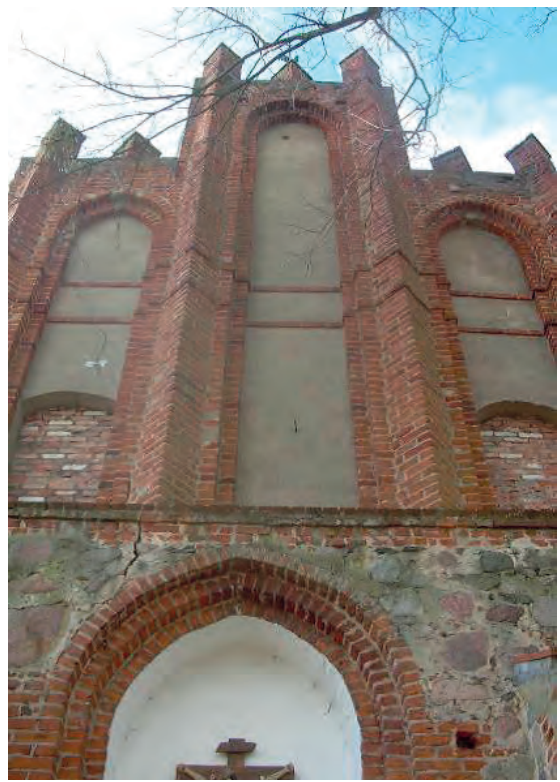

Ryc. 2. Kościół parafialny p.w. Bożego Ciała w Pręgowie od strony wschodniej, szczyt ceglany, I poł. XIV W. 
Niedawno odkryte piętnastowieczne freski w kościele parafialnym...

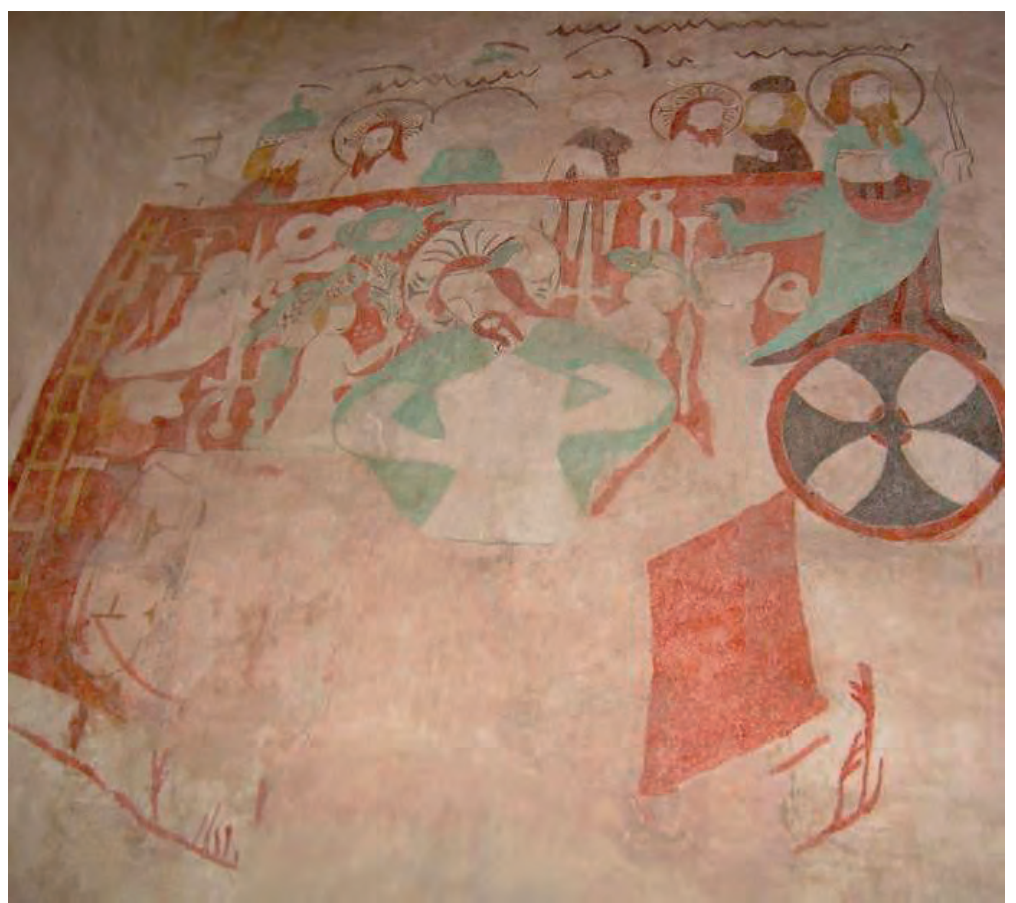

Ryc. 3. Wyobrażenie Chrystusa w otoczeniu Arma Passionis, I poł. XV w.

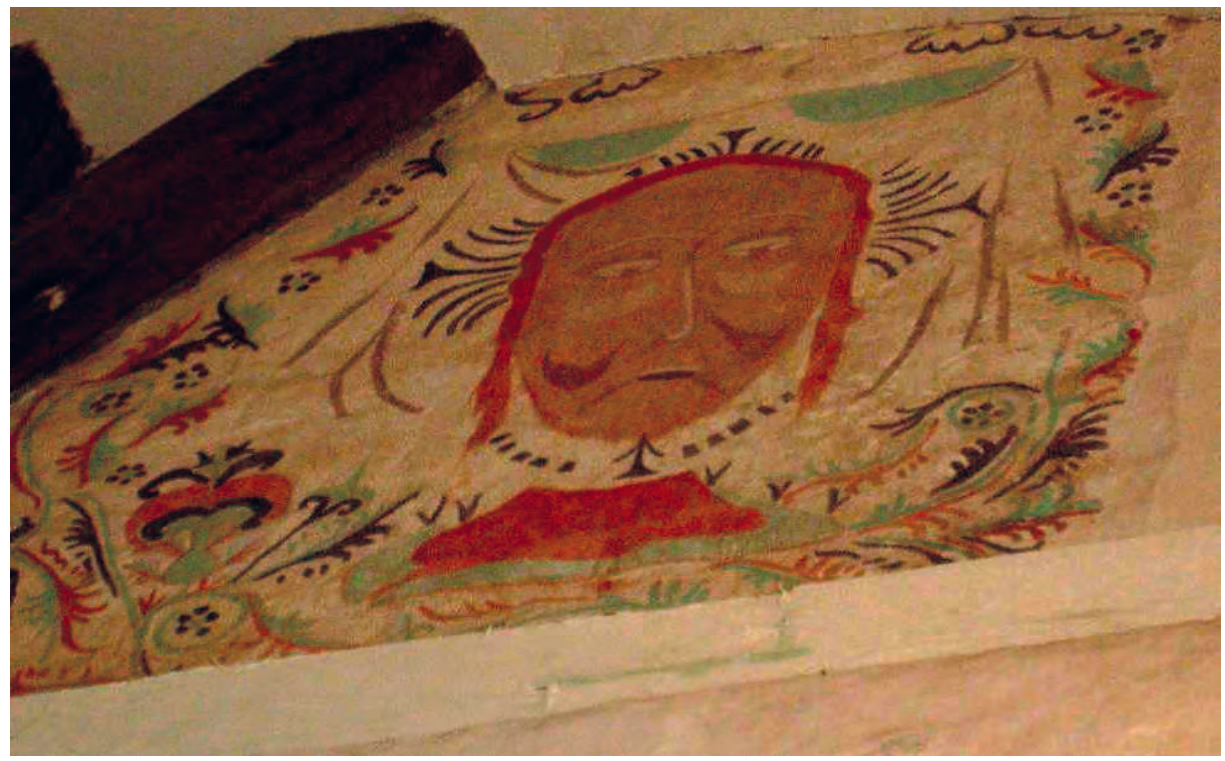

Ryc. 4. Przedstawienie Veraiconu, I pot. XV w. 
Gabriela Zbirohowska-Kościa

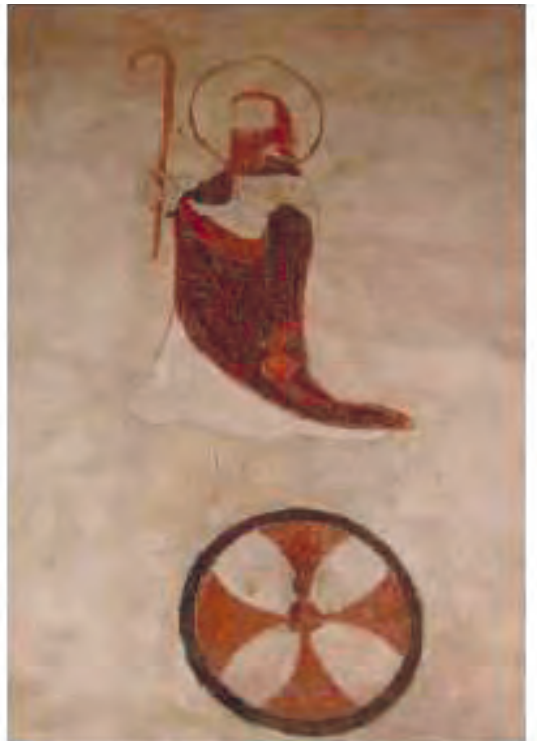

Ryc. 5. Przedstawienie św. Jakuba Młodszego Apostoła, I poł. XV w.

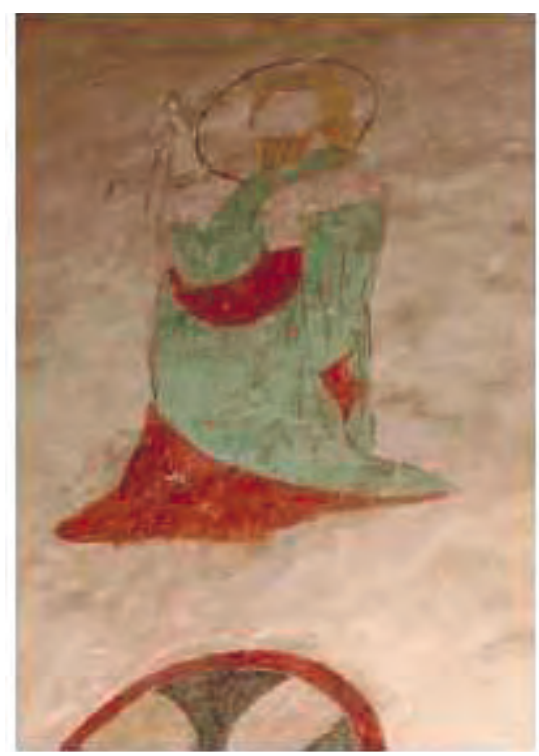

Ryc. 6. Przedstawienie św. Filipa Apostoła, I poł. XV w. 
Niedawno odkryte piętnastowieczne freski w kościele parafialnym...

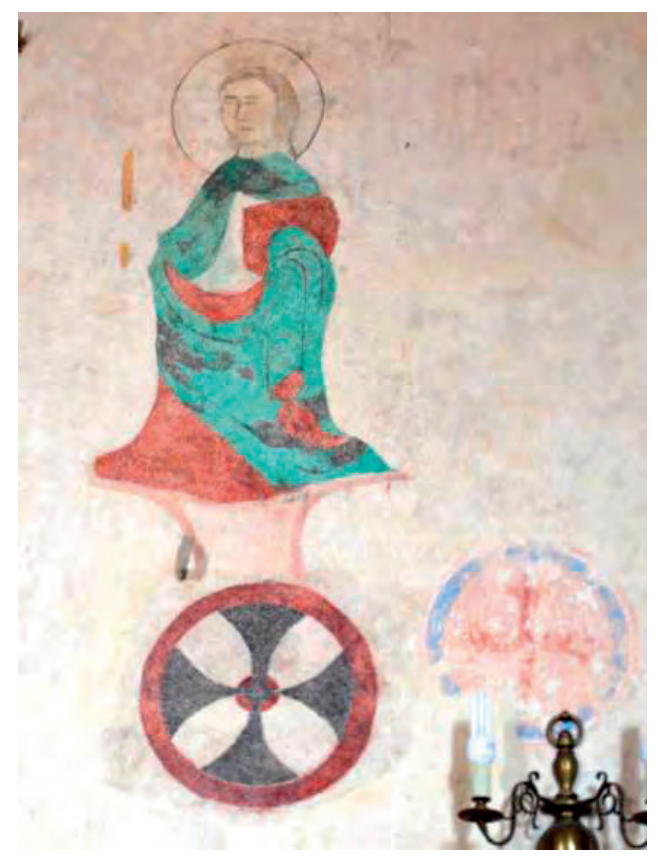

Ryc. 7. Przedstawienie św. Bartłomieja Apostoła, I poł. XV w.

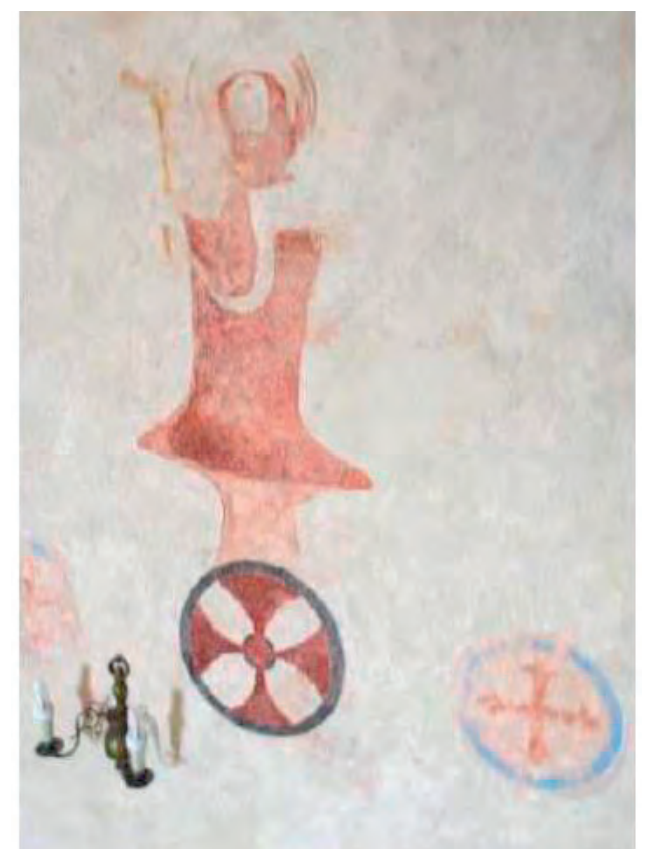

Ryc. 8. Przedstawienie św. Tomasza Apostoła, I poł. XV w. 
Gabriela Zbirohowska-Kościa

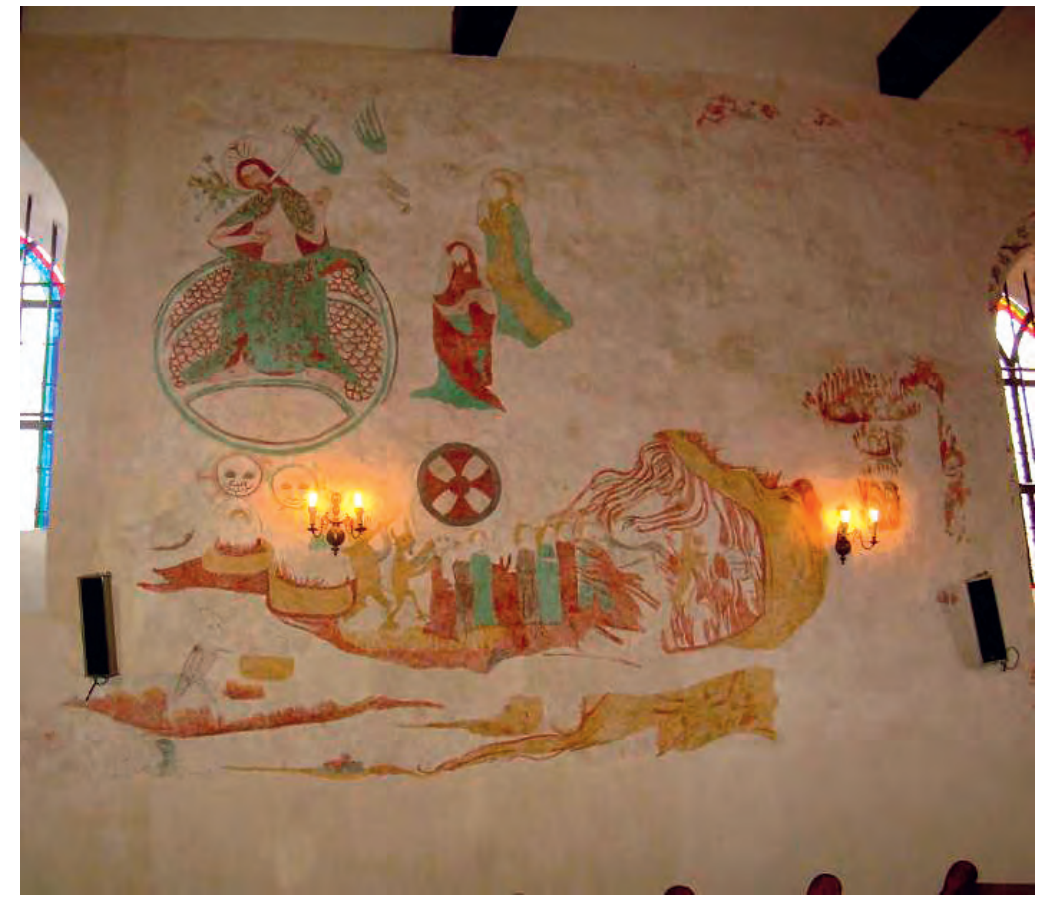

Ryc. 9. Przedstawienie Sądu Ostatecznego, I poł. XV w.

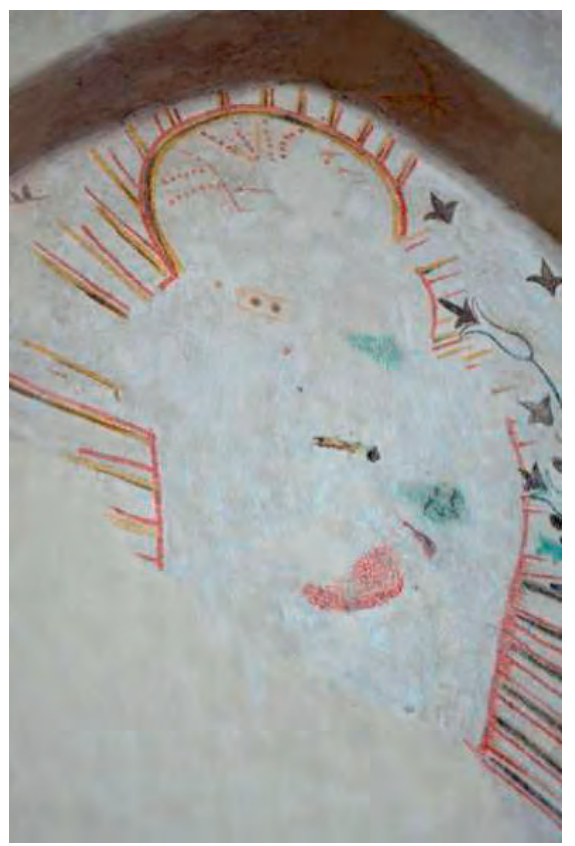

Ryc. 10. Przedstawienie Matki Boski Apokaliptycznej na ścianie tarczowej nad wejściem do zakrystii, I pot. XV w. 
Niedawno odkryte piętnastowieczne freski w kościele parafialnym...

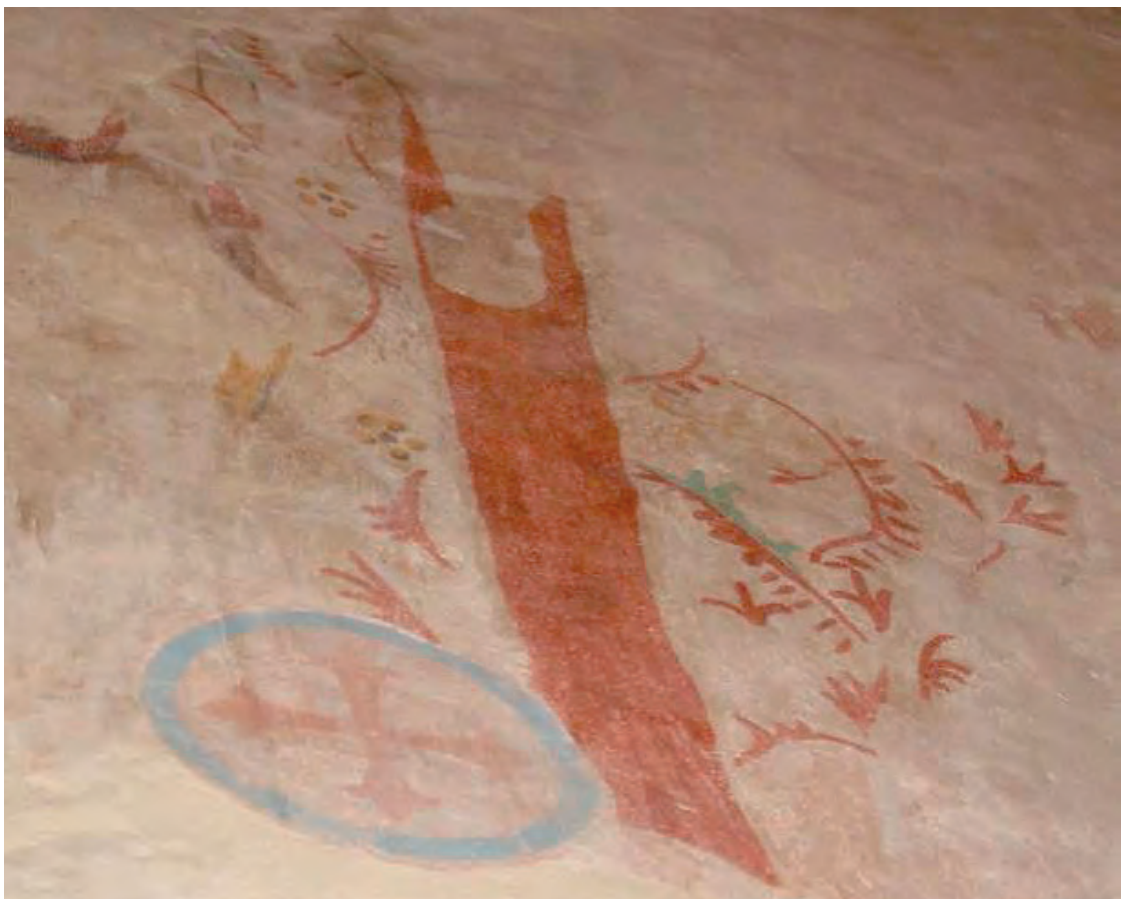

Ryc. 11. Fragment sceny Ukrzyżowania, I poł. XV w. 
Gabriela Zbirohowska-Kościa

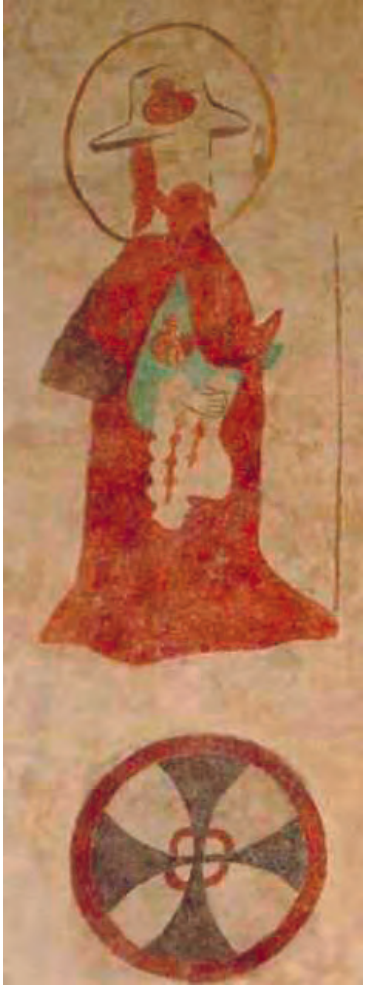

Ryc. 12. Przedstawienie św. Jakuba Starszego Apostoła, I poł. XV w.

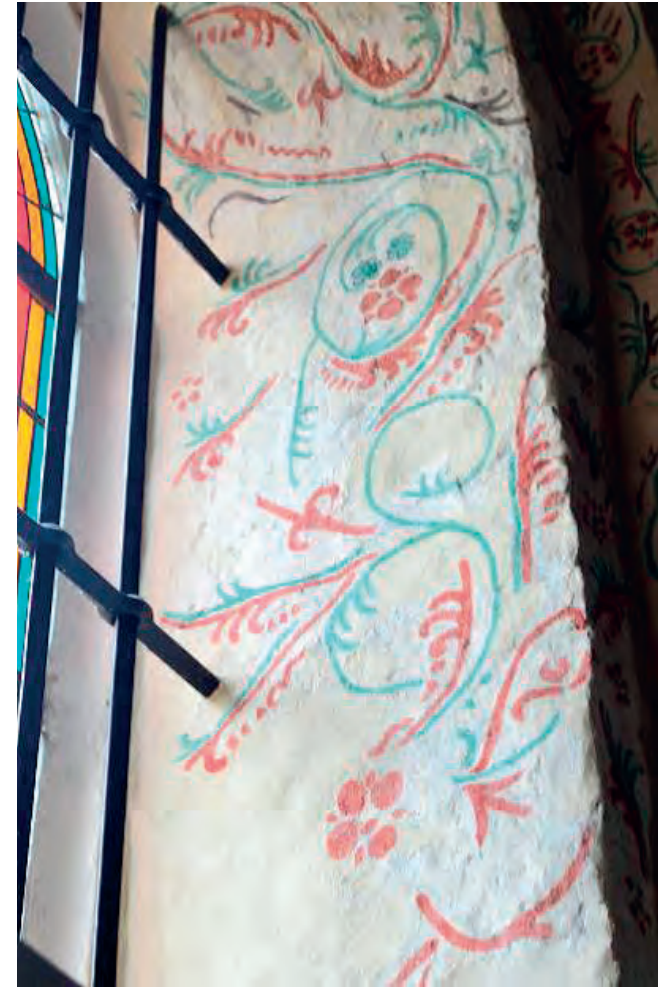

Ryc. 13. Dekoracja ościeży glifu okiennego z motywem wici roślinnej, I poł. XV w.

Zdjęcia wykonała Gabriela Zbirohowska-Kościa 